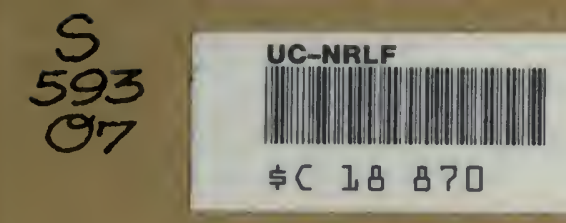


(n) -

$-$ 

Main l.ib,

Anric. bet,

\section{THE ANTAGONISTIC ACTION OF MAGNESIUM AND POTASSIUM}

\section{W. J. V. OST ER HOUT \\ (WITH THREE FIGURES)}

It has been previously pointed out that potassium may inhibit more or less fully the poisonous effects of magnesium and that the abundance of potassium in the soil makes this inhibitory action of importance in soil investigations. I $\mathrm{OEEW}$ and $\mathrm{AsO}^{2}$ have criticized this statement. Their objections are that only chlorids were used and that no flowering plants were investigated. In the present paper these objections are fully met. The experiments extend over a wide range of forms and their general agreement furnishes conclusive proof of the above-mentioned action of potassium.

The technique employed has already been described in previous papers in this journal. ${ }^{3}$ The material was placed in glass dishes containing $100-300^{\mathrm{cc}}$ of the solution and was covered with glass plates to exclude dust and hinder evaporation. Water twice distilled and salts which were tested for purity were used throughout. The results given in the tables are in all cases averages of several series of experiments.

The first experiments were made upon a marine alga, Enteromorpha Hopkirkii, which is able to live in both sea water and distilled water. It was taken from the sea water, rinsed in distilled water, and placed directly in the solutions. The solutions used were of the concentration $0.375 \mathrm{~m}$, which has the same osmotic pressure as the sea water in which the plants naturally grow.

In pure $\mathrm{MgCl}_{2} .0375 \mathrm{~m}$ they lived but four days; in pure $\mathrm{KCl} .0375 \mathrm{~m}$ seven days; while in distilled water and sea water they were alive and vigorous at the end of twenty days when the experiment was discontinued. It is evident therefore that both $\mathrm{KCl}$ and $\mathrm{MgCl}_{2}$ have a poisonous action.

This poisonous effect largely disappears if we mix the two salts

I Osterhout, University of California Publications, Botany 2:235. 1906.

2 Loew and Aso, Bull. Imp. Coll. Agr. Tokyo 7:395. 1907.

3 OSterhout, Bot. GAzETTE 42:I27-I34. I906; 44:259-272. I907.

[Botanical Gazette, vol. 45 
$\left(\mathrm{MgCl}_{2}\right.$ and $\left.\mathrm{KCl}\right)$ in proper proportions. In the mixture $100^{\mathrm{cc}} \mathrm{MgCl}_{2}$ $+40^{\mathrm{cc}} \mathrm{KCl}$, the plants were alive and in good condition at the end of twenty days, when the experiment was discontinued. It is evident therefore that in the mixture of magnesium and potassium chlorids the plants live five times as long as in pure magnesium chlorid and three times as long as in pure potassium chlorid.

TABLE I

marine Algae

All quantities given are cubic centimeters of $0.375 \mathrm{~m}$ solutions

\begin{tabular}{|c|c|}
\hline Culture solution & $\begin{array}{l}\text { Duration of life in } \\
\text { days: Eniero- } \\
\text { morpho Hopkirkii }\end{array}$ \\
\hline 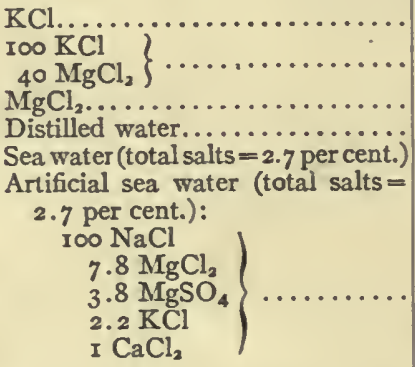 & $\begin{array}{c}7 \\
20+ \\
4 \\
20+ \\
20+\end{array}$ \\
\hline
\end{tabular}

The plus sign indicates that the plants were alive at the end of the experiment.

The results obtained from the study of Vaucheria were even more striking. Zoospores were allowed to attach themselves to slides. These were then rinsed in distilled water and placed in the solutions. The results are shown in the following table and also in fig. $I$.

TABLE II

Fresh-water Algae

All quantities given are cubic centimeters of .or $m$ solutions

\begin{tabular}{|c|c|c|}
\hline \multirow[b]{2}{*}{ CULTURE SOLUTioN } & \multicolumn{2}{|c|}{$\begin{array}{l}\text { DEVELOPMENT DURING } 45 \text { DAYS: } \\
\text { Vaucheria letrestris }\end{array}$} \\
\hline & $\begin{array}{l}\text { Length of } \\
\text { thallus } \\
\text { in } \mathrm{mm} \text {. }\end{array}$ & $\begin{array}{l}\text { Percentage of } \\
\text { increase } \\
\text { in length }\end{array}$ \\
\hline 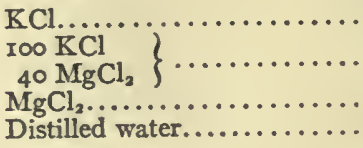 & $\begin{array}{l}0.15 \\
6.45 \\
0.15 \\
10.0\end{array}$ & $\begin{array}{c}0 \\
4200 \\
0 \\
6566.66\end{array}$ \\
\hline
\end{tabular}


A large Spirogyra of the majuscula type was used for experiments with the stronger solutions. The results are given in Table III.

TABLE III

FRESH-WATER ALGAE

All quantities given are cubic centimeters of $.0937 \mathrm{~m}$ solutions

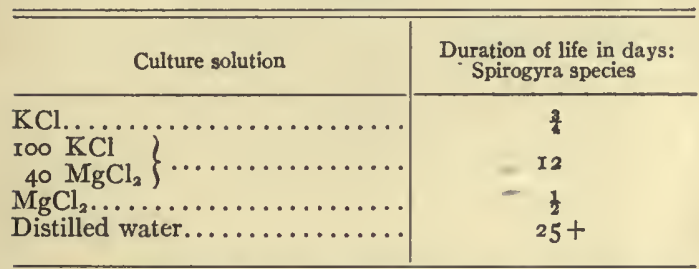

The plus sign indicates that the plants were alive at the end of the experiment.

A series of experiments was next made with the gemmae of Lunularia. These were allowed to float on the surface of the solutions. A large number was used and the average results given in the following table.

\section{TABLE IV \\ LIVERWORTS}

All quantities given are cubic centimeters of $.0937 \mathrm{~m}$ solutions

\begin{tabular}{|c|c|}
\hline Culture solution & $\begin{array}{l}\text { Duration of life } \\
\text { in days: } \\
\text { gemmae of Lunularia }\end{array}$ \\
\hline $\mathrm{KCl} \ldots \ldots \ldots \ldots \ldots \ldots$ & 12 \\
\hline $\begin{array}{r}\text { roo } \mathrm{KCl}_{50} \mathrm{MgCl}_{2} \\
\mathrm{MgCl}\end{array} \ldots \ldots \ldots \ldots \ldots \ldots$ & $\mathrm{I} 20+$ \\
\hline $\left.\begin{array}{l}\text { I00 } \mathrm{KCl} \\
\text { I00 } \mathrm{MgCl}_{2}\end{array}\right\} \ldots \ldots \ldots \ldots \ldots \ldots$ & $\mathrm{x} 20+$ \\
\hline $\left.\begin{array}{c}50 \mathrm{KCl} \\
\text { I } \mathrm{MgCl}_{2}\end{array}\right\} \ldots \ldots \ldots \ldots \ldots \ldots \ldots$ & 100 \\
\hline $\mathrm{MgCl}_{2} \ldots \ldots \ldots \ldots \ldots$ & 4 \\
\hline Distilled water........... & $\mathrm{x} 20+$ \\
\hline
\end{tabular}

The plus sign indicates that the plants were alive at the end of the experiment.

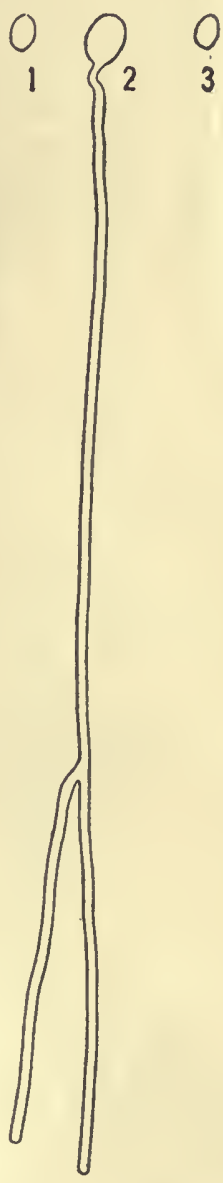

Fig. I.-Growth of Vaucheria during 45 days in .ox $m$ solutions. $I, \mathrm{KCl}$, gain o; 2, roocc $\mathrm{KCl}$ $+{ }_{40 \mathrm{occ}} \mathrm{MgCl}_{2}$, gain $4200 \% ; 3, \mathrm{MgCl}_{2}$, gain 0 . $\times 25$. 
It will be noticed even when magnesium greatly preponderates in the mixed solutions the plants live twenty-five times as long as in pure $\mathrm{MgCl}_{2}$, and over eight times as long as in pure $\mathrm{KCl}$. Increasing the proportion of potassium increases the length of life.

The same relation is seen more completely in the next table (Table V). Decreasing the amount of $\mathrm{Mg}$ causes increased growth up to a certain point (100 K+10 Mg). Still further decrease of the relative amount of $\mathrm{Mg}$ beyond this point is unfavorable. The optimum relation is therefore not far from $10 \mathrm{Mg}+100 \mathrm{~K}$.

\section{TABLE V}

LIVER WORTS

All quantities given are cubic centimeters of $.0375 \mathrm{~m}$ solutions

\begin{tabular}{|c|c|c|}
\hline \multirow{2}{*}{ CULture solutiox } & \multicolumn{2}{|c|}{$\begin{array}{l}\text { GROWTH IN } 150 \text { DAYS: GEURAE } \\
\text { OF LUNULARIA }\end{array}$} \\
\hline & $\begin{array}{l}\text { Length of } \\
\text { thallus } \\
\text { in } \mathrm{mm} \text {. }\end{array}$ & $\begin{array}{l}\text { Percentage of } \\
\text { gain in length } \\
\text { of thallus }\end{array}$ \\
\hline $\mathrm{KCl} \ldots \ldots \ldots \ldots$ & 0.5 & 0 \\
\hline $\left.\begin{array}{r}100 \mathrm{KCl} \\
5 \mathrm{MgCl}_{2}\end{array}\right\} \ldots \ldots \ldots$ & $3 \cdot 30$ & 560 \\
\hline $\left.\begin{array}{l}\text { I00 } \mathrm{KCl} \\
\text { 10 } \mathrm{MgCl}_{2}\end{array}\right\} \ldots \ldots \ldots$ & $3 \cdot 4 \mathrm{I}$ & $5^{82}$ \\
\hline$\left.{ }_{25}^{100 \mathrm{KCl}} \mathrm{MgCl}_{2}\right\} \ldots \ldots$ & 2.6 & 420 \\
\hline $\mathrm{MgCl}_{2} \ldots \ldots \ldots$ & 0.5 & $\circ$ \\
\hline Distilled water..... & 0.60 & 1220 \\
\hline
\end{tabular}

It will be noticed also that the gemmae made no growth whatever in pure $\mathrm{MgCl}_{2}$ or pure $\mathrm{KCl}$, while in mixtures of the two a good growth occurred.

For the study of flowering plants wheat was chosen. The seeds were supported in the solutions on strips of filter paper as described in a previous paper. ${ }^{4}$ The results agree with those already given. Table VI shows that certain mixtures of potassium chlorid and magnesium chlorid are much more favorable than either of the pure salts (see also figs. 2, 3).

4 Osterhout, Bot. Gazette 44:259-272. Ig07. 
Turning now to the experiments with sulfates and nitrates, we see entirely similar results, save that the mixed solutions, while better than pure magnesium salts, are not better than pure potassium salts. The question might then arise whether the favorable result is due in this case to mere dilution of magnesium salts with less poisonous ones. This, however, is not the case. We are dealing with a true antagonistic action. This is shown by the fact that addition of the potassium salt in solid form likewise produces a favorable result, and also by the fact that the addition of pure water does not produce anything like

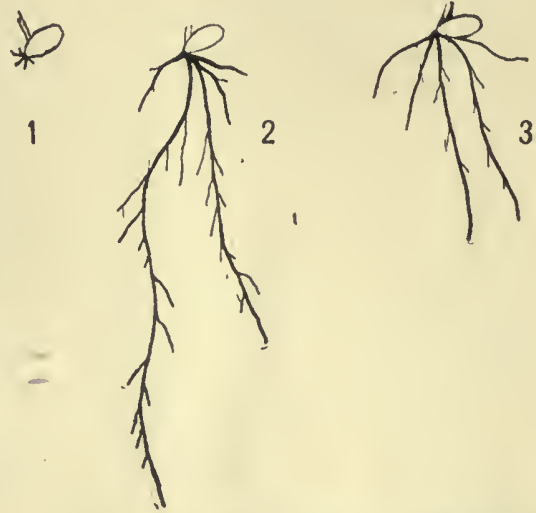

FIG. 2.-Growth of wheat roots during 40 days in $.0937 m$ solutions: $I, \mathrm{MgCl}_{2}$, aggregate length of roots $10 \mathrm{~mm} ; 2$, I00cc $\mathrm{KCl}+25^{\mathrm{cc}} \mathrm{MgCl}_{2}$, aggregate length of roots $153^{\mathrm{mm}} ; 3, \mathrm{KCl}$, aggregate length of roots Iromm. $\times \frac{2}{3}$.

the improvement seen on the addition of the same amount of a solution of a potassium salt.

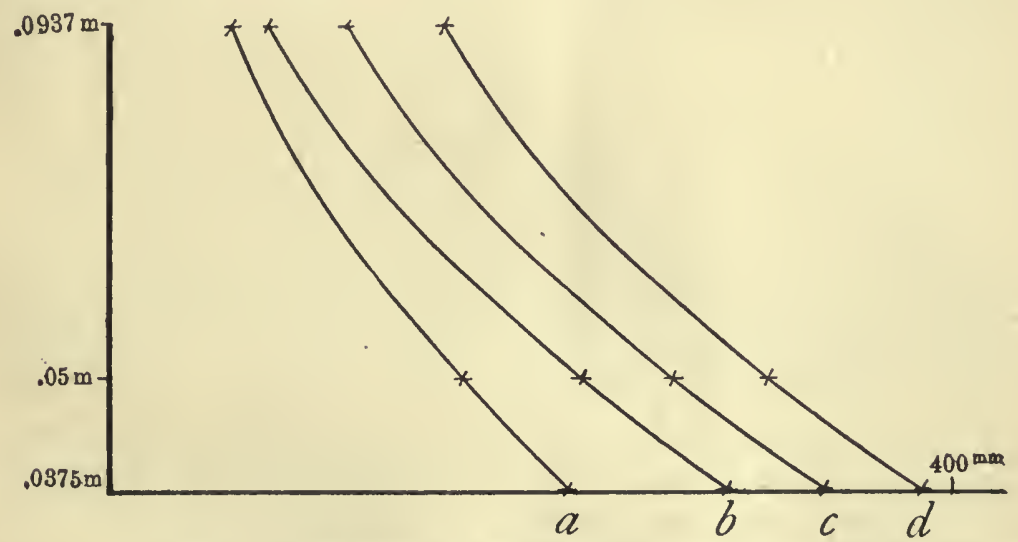

FIG. 3.-Curves showing growth of wheat roots in salt solutions. The ordinates represent concentrations (parts molecular); the abscissae represent the aggregate length of roots per plant in millimeters. $a$, roocc $\mathrm{KCl}+100$ cc $\mathrm{MgCl}_{2} ; b$, 100cc $\mathrm{KCl}$ $+5^{\text {occ }} \mathrm{MgCl}_{2} ; c, \mathrm{KCl} ; d$, $100 \mathrm{cc} \mathrm{KCl}+25^{\mathrm{cc}} \mathrm{MgCl}_{2}$. 
TABLE VI

WHEAT

\begin{tabular}{|c|c|c|c|}
\hline \multirow{2}{*}{$\begin{array}{l}\text { CULTURE SOLUTION } \\
\text { QUANTITIES IN } \subset \text { C. }\end{array}$} & \multicolumn{3}{|c|}{$\begin{array}{l}\text { GROWTH DURNG } 60 \text { DAYS } \\
\text { AGGREGATE LENGTH OF ROOTS PER PLANT IN MOS. }\end{array}$} \\
\hline & In .0937 m solutions & In .05 $\mathrm{m}$ solutions & In $.0375 m$ solutions \\
\hline $\mathrm{KCl}, \ldots, \ldots, \ldots \ldots \ldots \ldots$ & Iro & 268 & 340 \\
\hline $\left.\begin{array}{l}100 \mathrm{KCl} \\
100 \mathrm{MgCl}_{2}\end{array}\right\} \ldots \ldots \ldots \ldots \ldots$ & 66 & 170 & 220 \\
\hline $\left.\begin{array}{r}100 \mathrm{KCl} \\
50 \mathrm{MgCl}_{2}\end{array}\right\}$ & 72 & 224 & 294 \\
\hline $\begin{array}{r}100 \mathrm{KCl}_{2} \mathrm{MgCl}_{2} \\
25 \ldots \ldots \ldots \ldots \ldots\end{array}$ & I53 & $3^{12}$ & 388 \\
\hline $\mathrm{MgCl}_{2} \ldots$ & ro & 20 & 28 \\
\hline $\left.\begin{array}{l}5 \circ \mathrm{K}_{2} \mathrm{SO}_{4} \\
5 \circ \mathrm{H}_{2} \mathrm{O}\end{array}\right\}$ & 80 & 216 & 276 \\
\hline $\left.\begin{array}{r}50 \mathrm{~K}_{2} \mathrm{SO}_{4} \\
\mathrm{r} \infty \mathrm{MgSO}_{4}\end{array}\right\}$ & $3^{6}$ & I I 2 & I 44 \\
\hline $\left.\begin{array}{l}5 \circ \mathrm{K}_{2} \mathrm{SO}_{4} \\
50 \mathrm{MgSO}_{4}\end{array}\right\}$ & 48 & 148 & 190 \\
\hline $\left.\begin{array}{l}5 \circ \mathrm{K}_{2} \mathrm{SO}_{4} \\
25 \mathrm{MgSO}_{4}\end{array}\right\} \ldots \ldots \ldots \ldots \ldots \ldots$ & 60 & r66 & 240 \\
\hline $\mathrm{MgSO}_{4} \ldots \ldots \ldots \ldots \ldots$ & 4 & 10 & 24 \\
\hline $\mathrm{KNO}_{3} \ldots \ldots \ldots \ldots$ & II 4 & 275 & 345 \\
\hline $\left.\begin{array}{l}100 \mathrm{KNO}_{3} \\
100 \mathrm{Mg}\left(\mathrm{NO}_{3}\right)_{2}\end{array}\right\} \ldots \ldots \ldots \ldots \ldots$ & I 2 & 76 & IO4 \\
\hline $\left.\begin{array}{r}100 \mathrm{KNO}_{3} \\
50 \mathrm{Mg}\left(\mathrm{NO}_{3}\right)_{2}\end{array}\right\} \ldots \ldots \ldots \ldots \ldots$ & $3^{2}$ & I44 & IgS \\
\hline $\left.\begin{array}{r}100 \mathrm{KNO}_{3} \\
{ }_{25} \mathrm{Mg}\left(\mathrm{NO}_{3}\right)_{2}\end{array}\right\} \ldots \ldots \ldots \ldots \ldots$ & 80 & 224 & 290 \\
\hline $\mathrm{Mg}\left(\mathrm{NO}_{3}\right)_{2} \ldots \ldots \ldots \ldots$ & $3 \cdot 5$ & 8 & Io \\
\hline Distilled water............ & \multicolumn{3}{|c|}{740} \\
\hline
\end{tabular}

Since each molecule of $\mathrm{K}_{2} \mathrm{SO}_{4}$ yields two $\mathrm{K}$ ions, half as much $\mathrm{K}, \mathrm{SO}_{4}$ is used as $\mathrm{KCl}$ or $\mathrm{KNO}_{3}$. The figures for $50 \mathrm{~K}_{2} \mathrm{SO}_{4}+50 \mathrm{H}_{2} \mathrm{O}$ are comparable with the corresponding figures for $\mathrm{KCl}$ and $\mathrm{KNO}_{3}$, though the concentration of the solution is only half as great. For example, the roots reach a length of $80^{\mathrm{mm}}$ in $5^{\mathrm{ce}} \mathrm{K}_{3} \mathrm{SO}_{4} .0937 \mathrm{~m}+5^{\circ 0} \mathrm{H}_{2} \mathrm{O}$; a length of $216^{\mathrm{mm}}$ in $50^{\circ 0} \mathrm{~K}, \mathrm{SO}_{4} .05 \mathrm{~m}+50^{\mathrm{cc}} \mathrm{H}_{2} \mathrm{O}$; and a length of $276^{\mathrm{mm}}$ in $50^{\circ \mathrm{cc}} \mathrm{K}_{2} \mathrm{SO}_{4} .0375 m+50^{\mathrm{cc}} \mathrm{H}_{3} \mathrm{O}$.

It will be noticed that these antagonistic effects are less marked as the concentration is lowered. This is of course true of all antagonistic action, since as the concentration is lowered toxicity diminishes and the effect of its inhibition is consequently less striking.

It is observed that those parts which are in direct contact with solutions always show their effects much more plainly than those 
(e. g., leaves and stems) which are raised above them. It seemed desirable therefore to find out how sections of stems and roots would behave in the solutions. The answer to this question is given in Table VII. Transverse sections of the stem of Tradescantia and the root of the common red beet were employed. They were cut on a microtome and were of considerable but uniform thickness.

\section{TABLE VII \\ Cuttings and Sections}

All quantities given are cubic centimeters of $.0937 m$ solutions

\begin{tabular}{|c|c|c|c|}
\hline \multirow[b]{2}{*}{ Culture solution } & \multicolumn{2}{|c|}{ DURATION OP LIFE IN DAYS } & \multirow{2}{*}{$\begin{array}{l}\text { Development } \\
\text { Cuttings } 15^{\mathrm{cm}} \\
\text { long of } \\
\text { Tradescantia }\end{array}$} \\
\hline & $\begin{array}{l}\text { Microtome sections } \\
\text { of stem of } \\
\text { Tropacolum majus }\end{array}$ & $\begin{array}{l}\text { Microtome sections } \\
\text { of root of } \\
\text { Beta vulgaris }\end{array}$ & \\
\hline 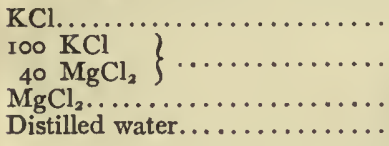 & $\begin{array}{l}20 \\
28+ \\
20 \\
28+\end{array}$ & $\begin{array}{l}14 \\
27 \\
18 \\
28+\end{array}$ & $\begin{array}{l}\text { No roots } \\
\text { Short roots } \\
\text { No roots } \\
\text { Long roots }\end{array}$ \\
\hline
\end{tabular}

A plus sign indicates that the plants were alive at the end of the experiment.

In both cases the color and microscopic appearance served as the criterion of death. As is seen in Table VII, the results agree with those already obtained. The table likewise shows the results obtained from cuttings of Tradescantia (about $15^{\mathrm{cm}}$ long) which were placed with their lower ends in the solutions.

In view of the striking agreement of results obtained from such a variety of material, it seems useless to seek for further proof. The experiments of LOEW and Aso also show antagonism between potassium and magnesium, as far as they go. They do not, however, employ sufficient potassium (nor sufficiently strong solutions) to bring out the results clearly. The use of percentage solutions (rather than molecular solutions) likewise obscures their results. More fundamental is their confusion of physiologically balanced solutions with ordinary nutrient solutions. ${ }^{5}$

As for the theory of LoEw and Aso that the inhibitory action of potassium on magnesium is due to the formation of a double salt: $\mathrm{I}_{\text {: }}$

5 Cf. OsterHout, On nutrient and balanced solutions. University of Californla Publications, Botany 2:317. 1907; also, Bот. GAzeTtE 44:259-272. 1907.

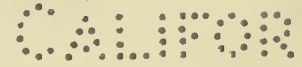


need merely say that it cannot be true because this inhibitory action is seen in mixtures of potassium nitrate and magnesium nitrate where no double salt is formed. Moreover, even in the chlorids and sulfates the formation of a double salt cannot much affect the result, since the double salt, at the concentrations here used, dissociates and sets free magnesium and potassium ions to almost the same extent as the simple salts.

\section{RESULTS}

Magnesium salts and potassium salts, used separately, are poisonous to plants, but when mixed together (in suitable proportions) the poisonous effects more or less completely disappear. These results are of importance in soil investigations.

University of Califoria

Berkeley 




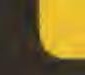

8 


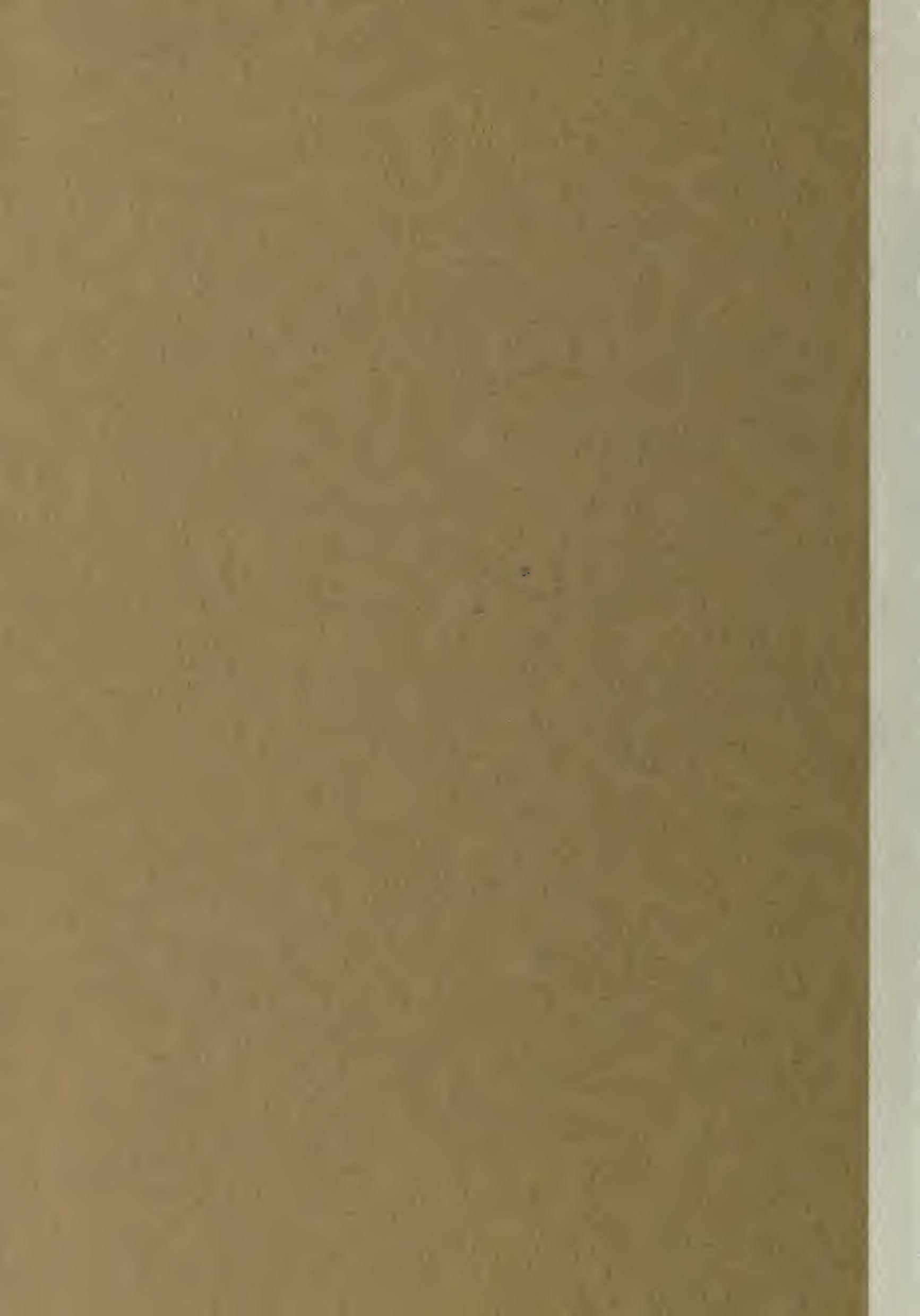

